\title{
EXPLORING THE LANGUAGE CHOICE OF THE NON-COMMERCIAL SIGNS IN JAKARTA'
}

\author{
Anna Marietta da Silva \\ Unika Atma Jaya, Indonesia \\ anna.silva@atmajaya.ac.id
}

First received: 20 December 2016

Final proof received: 22 September 2017

\begin{abstract}
This article focuses on non-commercial signs in the linguistic landscape of Jakarta. Five main streets within or nearby the centroid of Jakarta are selected. The prevalence of English and the use of English words in the non-commercial signs are examined. The data cover 47 non-commercial signs which are investigated from the perspective of place semiotics. Despite their small number, this category of sign, mainly those that belong to the Regulatory discourse, holds a legal power. The presence of the non-commercial signs signifies the power of the state and communicates vertical and horizontal relationships between the authority and the audience. The findings suggest that the Infrastructural discourse is mostly available and Indonesian is the dominant language. English is present to a certain extent, particularly with regard to content related to technology and English prestigious status. Semantically, few English words had meaning extension when used in Indonesian context. The language choice of the non-commercial signs indicates the exclusiveness of Jakarta linguistic landscape.
\end{abstract}

Keywords: linguistic landscape; non-commercial signs; semiotics; English

The notion linguistic landscape (hereafter referred to as LL) concerns languages that are displayed within a specific area (Landry \& Bourhis, 1997), namely inside a city (Gorter, 2006). Reading public signs in LL is challenging as LL reflects historical, political, economic, geographical, and social relationships between the audience and the sign authors (Huebner, 2016). In line with the growing amount of research in LL, the definition has been reformulated in accordance with the approach taken by the researchers and the findings they presented. LL includes not only language (Koskinen, 2012), but objects that symbolize people's belief, culture, and action (Ben-Rafael, Shohamy, Amara, \& Trumper-Hecht, 2006). In other words, the placement of language in public areas is connected to the social and tangible setting nearby (Scollon \& Scollon, 2003). More than that, LL is seen as particular descriptions of one place that are derived from the audience's interpretation of the written signs which in themselves reflect complex relationship between meanings and places (Stroud \& Jegels, 2013) LL may also refer to the "manifestation of political and economic interests through the use of languages" (da Silva, 2016, p. 229), which implies that LL is dependent on the political and economic decisions made by the sign authors.

Discussion about LL encompasses the sign authors as well. The authorship of the signs in LL has been categorized into two: the government and the private parties (Landry \& Bourhis, 1997). The former is called the top-down and the latter the bottom-up signs (Ben-Rafael, et al., 2006). The top- down signs are also known as the official signs, while the bottom-up the non-official signs. The difference between the two lies in these two aspects: variety of signs and language presentation. Topdown signs commonly include names of streets, writing on buildings and facilities that belong to the governments, banners or posters within the government offices, road signs, writing in public facilities such as hospitals, train stations, schools, campuses, parks, and many more, whereas bottomup signs cover commercial banners, posters, billboard advertisements, mobile advertisements on vehicles, and balloons that are created or owned by private parties. With reference to the language presentation, the top-down signs are likely to present a limited number of languages, i.e. the national language and other languages that are officially recognized by the government, while the bottom-up signs may display other languages in addition to the official language(s) (Backhaus, 2006).

The categories of sign authorship are useful when the division between the official and nonofficial is clear and strict. Yet, there can be cases in which the official party (the government) assigns a private party to run a public facility, as what happens in Jakarta, the capital city of the Republic of Indonesia. For example, PT. Transportasi Jakarta or Transjakarta is an enterprise owned by Jakarta Provincial Government. The company is assigned to manage the bus rapid transit, which is publicly known as 'busway' (PT. Transportasi Jakarta, 2016). Hence, to categorize whether the signs of Transjakarta belong to the government or the private 
parties can be quite complicated. Therefore, the category of commercial and non-commercial signs was selected in the present study (da Silva, 2016).

Scollon and Scollon (2003) incorporated the government and the private signs (as well as the social actors, the interaction between the actors, the visual and the place semiotics) into the study of the meaning of language in this physical world, hence Geosemiotics. In Geosemiotics, the government signs create a discourse, and it is classified into Regulatory and Infrastructural discourse. Other signs are categorized into commercial and transgressive discourses. The Regulatory discourse includes signs that have legal consequences, such as traffic lights, speed signs, pedestrian traffic, and public notices. The Infrastructural discourse contains signs that are related to the infrastructure such as "water, power, and gas" (Scollon \& Scollon, 2003, p. 185). Commercial discourse is connected to business, and Transgressive discourse covers graffiti and other signs not included in the previous three discourses.

Previous research on LL found that English was not the most preferable language for noncommercial signs. It was the local or national language that became the identity of the top-down signs in several cities, such as Israel, Tokyo and Timor Leste (Ben-Rafael, et al., 2006; Backhaus, 2006; Macalister, 2012). Specifically, Hebrew was dominant on the top-down signs in different localities. In Jewish locality, signs containing only Hebrew were dominant; in Israeli-Palestinian locality, signs displaying Hebrew and Arabic were mostly found; and in East Jerusalem signs that consisted of Hebrew, Arabic, and English were most frequent (Ben-Rafael et al., 2006). Similarly, most non-official signs (both the monolingual and multilingual) in Tokyo used Japanese (Backhaus, 2006). However, English was frequent within the multilingual official signs. Official signs in Tokyo could thus be characterized by the occurrence of translations from Japanese into one or more than one language, indicating that the expected audience of the signs were not merely Japanese speakers, but also speakers of other languages, such as foreign business people and visitors. Likewise, Portuguese, not English, was the most preferable language for official signs in Timor Leste (Macalister, 2012).

Despite the predominance of national language on top-down signs, LL still provides an evidence of bilingualism or multilingualism of a city (Dixson, 2015; Huebner, 2016). Based on the languages that are present in LL, Backhaus (2006) categorized the multilingual signs into homophonic (signs that are written in one language with its translation), monophonic (signs that are written in one language only), and polyphonic (signs that utilize more than two languages). Drawing on Backhaus (2006), da Silva (2016) categorized the commercial signs in Jakarta LL into three: (1) monolingual, i.e. signs that consisted of English only, (2) bilingual, i.e. signs that displayed Indonesian-English translation, or vice versa, and (3) bilingualized, i.e. signs that contained English borrowing, code-mixing, codeswitching, and English idiosyncrasies.

The use of English in non-English speaking countries may result in typical English used in one place. Ooi (2001) proposed a Concentric Model of English words used in Singaporean context. Based on Ooi's proposal, da Silva (2016, pp. 225-226) suggested a "Constellation of English words in the Jakarta LL" that illustrates the English words borrowed in public signs in Jakarta (vide Figure 1). Group 1 was for the English words whose spoken and written forms were retained and consisted of four sub-groups: 1A (for operational English words such as .com, .ac.), 1B (for technical words such as notebook, steam), 1C (for prestigious words, such as $t$-shirt, e-mail), and 1D (for words that did not have their Indonesian equivalence, e.g. varsity, brownie). Group 2 was for the adapted English words (the spoken form) and was divided into three sub-groups: $2 \mathrm{~A}$ (for words related to the internet, e.g. $w w w$ ), 2B (for words related to technology, e.g. handphone, $A T M$ ), and $2 \mathrm{C}$ (for prestigious words, e.g. $W C$, service). Group 3 was for adjusted English words whose meaning is extended. Group 4 was for the modified English words (the written and spoken forms) and was classified into two sub-groups: 4A (for words about technology, e.g. HP, AC, refill) and 4B (for words that did not exist in Indonesian vocabulary, e.g. cornet)

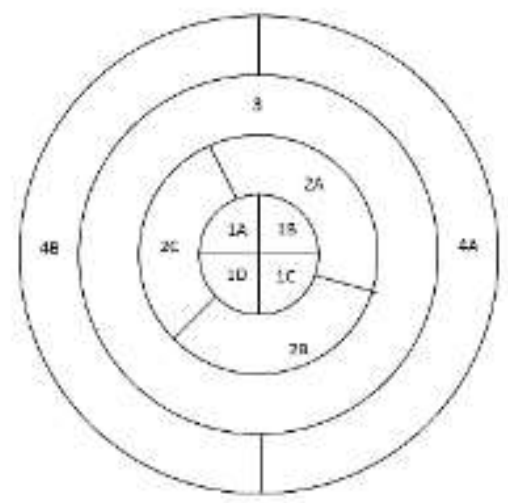

Figure 1. Constellation of English words in Jakarta LL

Earlier studies have shown the homogeneity and heterogeneity of languages used in LL (Backhaus, 2006; Cenoz \& Gorter, 2006). The dominance of powerful group was also represented in the dominance of its language in public signs through the language policy (Ben-Rafael et al., 2006). The extended diglossia (English being more prestigious than the local languages) was also evident in the LL of some areas; for instance, in Israeli and Portuguese LLs (Ben-Rafael et al., 2006; Torkington, 2009). Nevertheless, the discourse of non-commercial signs and the use of English on the non-commercial signs in Jakarta have not been 
explored deeply. In most of the earlier studies, the public signs collected were inclusive, i.e. all the signs present in the research areas. Furthermore, the idea of using centroid to gather data has never been introduced. Drawing from Scollon and Scollon's (2003) study, the present study investigates the presence of the non-commercial signs and seeks answer to these questions: (1) what does the language choice of the non-commercial signs in Jakarta convey? (2) to what degree is the prevalence of English in the non-commercial signs of Jakarta? and (3) why are English words used in the noncommercial signs? Public signs are composed of language, symbols, colours, pictures, or all of the previously mentioned elements. Nevertheless, the focus of the present study is the written words of the non-commercial signs and its objective is to describe the use of languages in non-commercial discourse. The following sections discuss how data were collected and analysed. Suggestions for further study can be read in the concluding remarks.

\section{METHOD}

The source of data for the present study was all noncommercial signs collected in commercial areas on or near the centroid of each administrative town in Jakarta. A centroid is the central point of an irregularly shaped area (Mulyana, 2014). A qualitative approach was selected in order to get a deep understanding of a phenomenon (Creswell, 2013). A sign in this study refers to texts that are placed in the landscape of a city (Gorter, 2006). LL refers to the collection of texts in public signs (Gorter, 2006).

The data collection process included: (1) determining a research area, i.e. main streets of the city that are commercial (Taylor-Leech, 2012) and located in or near the central point of an administrative town (da Silva, 2016); (2) photographing all signs within the area (Cenoz \& Gorter, 2006), i.e. signs that are placed on the streets or on the outer part of buildings, not inside the buildings (Backhaus, 2006; Edelman, 2010; Manan, David, Dumanig, \& Naqeebullah, 2015); (3) selecting only the non-commercial signs to be the research data, and (4) analysing the language displayed on the signs.

The authorship of a sign was based on the establishment; i.e. more than one sign was considered to be one single sign when it belonged to one establishment (Cenoz \& Gorter, 2006). Illegible signs were excluded from the data collection. The present study used words as the unit of analysis (Backhaus, 2006). Pictures, colours, numbers, international measurements, international symbols, mobile signs, graffiti, and proper names were not included in the research data. Repeated signs that belong to the same establishment were also excluded (Cenoz \& Gorter, 2006). The decision of not including the symbols, pictures, and proper names may not reflect the uniqueness of the noncommercial signs collected. Moreover, as the research areas covered only five centroids in Jakarta, the result may not be generalized.

In all of the research areas, only a few noncommercial signs were present (47 signs) in comparison to the commercial signs (324 signs). In Prapatan and Halim Perdanakusuma Roads there were only nine signs, respectively. Fewer signs in Baru Ancol Selatan Road ( $n=8)$ were collected and much fewer in Kembangan Baru $(n=3)$. Antasari Road had the highest number of non-commercial signs $(n=18)$.

The present study used the following theories to solve the research problems. To answer the first research question about the meaning of language choice, Scollon and Scollon's (2003) typology of discourse in Geosemiotics, particularly the place semiotics, Backhaus', Ben-Rafael et al.'s, and Macalister's findings on the dominance of local language in LL were adopted. To answer the second research question about the degree of English prevalence in LL, a typology of commercial signs that used English by da Silva (2016) was adopted. The non-commercial signs using English in the current study were also categorized into five, i.e. (1) signs that used only English words, (2) signs that used more English than Indonesian words, (3) signs that used half English and half Indonesian words, (4) signs that used fewer English than Indonesian words, and (5) signs that did not use any English words at all. To answer the third research question about the reason of using the English words in LL, da Silva's (2016) Constellation of English words in public signs was adopted.

\section{FINDINGS AND DISCUSSION}

This section starts with the results and discussion of the question about the typology of discourse of the non-commercial signs. The description of language usage is the primary focus. Not all of the authors were clearly identified in the signs. Some of the identified signs include the official organizations, such as the Jakarta Provincial Government, the Indonesian Federal Bank, the Indonesian Navy office, the Fire Department, the Indonesian Ministry of Finance, the Indonesian Ministry of Education, the District Court of North Jakarta, the Precinct Police of Tanjung Priok, and the Road Traffic and Transportation Service. Other authors were mass and Islamic organizations. Note that the main point is not the authorship, but the establishment. The discourse of the signs in all of the research areas was mostly Infrastructural (vide Table 1). In Prapatan, $89 \%$ of the signs were Infrastructural. The percentage was decreasing in Baru Ancol Selatan (75\%), Halim Perdanakusuma, Antasari, and Kembangan Baru (67\%, respectively). 
Table 1. Type of discourse in the five research areas

\begin{tabular}{clcc}
\hline \multirow{2}{*}{ No. } & \multirow{2}{*}{ Areas } & \multicolumn{2}{c}{ Type of Discourse } \\
\cline { 3 - 4 } & & Regulatory $(\mathrm{n}, \%)$ & Infrastructural $(\mathrm{n}, \%)$ \\
\hline 1. & Prapatan $(\mathrm{n}=9)$ & $(\mathrm{n}=1) 11.1 \%$ & $(\mathrm{n}=8) 88.9 \%$ \\
\hline 2. & Halim Perdanakusuma $(\mathrm{n}=9)$ & $(\mathrm{n}=3) 33.3 \%$ & $(\mathrm{n}=6) 66.7 \%$ \\
\hline 3. & Baru Ancol Selatan $(\mathrm{n}=8)$ & $(\mathrm{n}=2) 25.0 \%$ & $(\mathrm{n}=6) 75.0 \%$ \\
\hline 4. & Antasari $(\mathrm{n}=18)$ & $(\mathrm{n}=6) 33.3 \%$ & $(\mathrm{n}=12) 66.7 \%$ \\
\hline 5. & Kembangan Baru $(\mathrm{n}=3)$ & $(\mathrm{n}=1) 33.3 \%$ & $(\mathrm{n}=2) 66.7 \%$ \\
\hline
\end{tabular}

With regard to the language choice of the noncommercial signs, the findings indicate several factors. First, language is used for political reason. The use of Indonesian language is encouraged throughout the country. The Indonesian language is the primary language that must appear in public areas. The predominance of signs using only Indonesian language is consistent to the Law Number 24 Year 2009 and the Regulation of the Minister of Home Affairs Number 40 Year 2007 about the mandatory use of Indonesian language in public signs. The regulations stipulate that all public signs are written in Indonesian language. Specifically, in article \#36, it is noted that the mandatory language for names of buildings, streets, apartments, residences, offices, business centres, schools, and organizations that belong to the Indonesian citizens or legal organizations is Indonesian. The use of languages other than Indonesian, such as foreign and local languages, is allowed under several conditions, i.e. the foreign words were related to historical, cultural, traditional, and/or religious values. Meanwhile, article \#38 stipulates that Indonesian must be used for public signs, street directories, public facilities, banners, and other signs that are related to the public service. Local or foreign language may be used in addition to the Indonesian language.

Second, the language that is used on noncommercial signs is a means of communicating the authority's power. Note that the signs that belong to Regulatory, for instance, a stop sign, speed sign, and traffic lights are part of the law enforcement (vide Figure 2). Those signs are rigid and symbolize a top-down communication between the authority and audience. They are part of the authority's policy to ensure that the citizens obey the law. Thus, the authority is entitled to give penalties or sanctions to those breaking or ignoring the signs (Scollon \& Scollon, 2003). The homogeneity is reflected in the Regulatory discourse; the author of the Regulatory signs tends to be homogeneous, i.e. the Road Traffic and Transportation Service.

The service is responsible to the Ministry of Transportation. The authority of creating and placing the Regulatory signs is stipulated in the Regulation of the Ministry of Transportation No. 34 Year 2014 regarding Road Signs. In that regard, the content of the Regulatory signs also is likely to be uniform. Such homogeneity is not always presented by the signs of Infrastructural discourse, which is illustrated in Figure 3. As the name bears, the
Infrastructural discourse consists of signs that index to the infrastructure provided by the authority to the citizens (Scollon \& Scollon, 2003), such as a hydrant, dustbin, an exhaust emission checkpoint, and an absorbing well. The Infrastructural discourse is more fluid and may bear multiple meanings (Boogaart II, 2001).

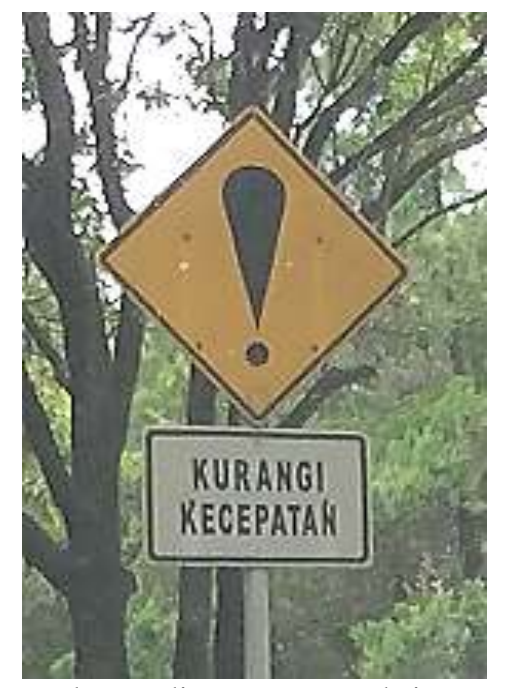

Figure 2. Regulatory discourse: speed sign

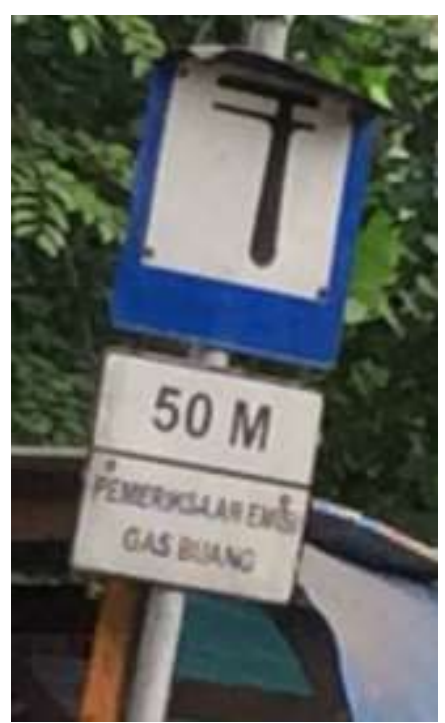

Figure 3. Infrastructural discourse: exhaust gas emission sign

The Infrastructural discourse tends to reveal both the vertical communication from the authority to the audience and the horizontal communication between the authorities and the audience. Take the 
sign shown in Figure 3 for example. That sign informs that within the next fifty metres an exhaust emission checkpoint is provided by the authority for the citizens (vertical communication). The information, e.g. the picture of the sign, can also be shared with other government institutions or by the citizens to other citizens (horizontal communication). Another example is the sign that reads "Hydrant". The sign does not only inform the audience that the authority has fulfilled its obligation of providing an important infrastructure for public interest (vertical communication), but also a sign for the other government institutions and for citizens to citizens. It can also deliver another message, i.e. a "warning" for the audience (both the authority and citizens) to be careful with the object. Indeed, one object can convey various meanings to multiple audiences. A material or object has its own role to construct the meaning of a place where it is located and sequentially contributes to the interpretation of meanings made by the audience (Stroud \& Jegels, 2013).

The prevalence of English language in the present study refers to the number of signs that used only English words. The study shows that English language is not dominant in all research areas. That is in line with the regulation about the use of language for signs in public areas. The Law No. 24 year 2009 and the Regulation of the Minister of Home Affairs Number 40 Year 2007 stipulate that Indonesian is the primary language of the signs. English and local language may be used in addition to Indonesian language. Details of the English prevalence are explained next.

In Prapatan Road, more than half of the signs (56\%) use no English words (vide Table 2.) The authors of the signs that employ signs without English words at all include the Jakarta province, Forum Betawi Rempug (a mass organization), the Police Mobile Brigade, and the Ministry of Finance of the Republic of Indonesia. Interestingly, there are non-commercial signs that use words in English, namely the Traffic and Transportation Service of Jakarta Province, the Indonesian Navy, and the Indonesian Federal Bank. In Halim Perdanakusuma Road, more than seventy percent of the signs do not use English. Less than thirty percent of the signs display English words. Similarly, in Baru Ancol Selatan Road, English is not dominant, with more than sixty percent of the signs use no English words. There are a small number of signs that use fewer English words (25\%) and more English words (13\%). In Antasari, signs that do not use English are above seventy percent and in Kembangan Baru, more than sixty percent of the signs do not display English.

Table 2. Indonesian prevalence of the non-commercial signs in 5 research areas

\begin{tabular}{llrrrrr}
\hline & & \multicolumn{5}{c}{ Language } \\
\cline { 3 - 7 } No. & Area & $\begin{array}{c}\text { All English } \\
(\mathrm{n}, \%)\end{array}$ & $\begin{array}{c}\text { More English } \\
(\mathrm{n}, \%)\end{array}$ & $\begin{array}{c}\text { Half English } \\
(\mathrm{n}, \%)\end{array}$ & $\begin{array}{c}\text { Fewer English } \\
(\mathrm{n}, \%)\end{array}$ & $\begin{array}{c}\text { No English } \\
(\mathrm{n}, \%)\end{array}$ \\
\hline 1. & Prapatan $(\mathrm{n}=9)$ & $(\mathrm{n}=1) 11.1 \%$ & $(\mathrm{n}=0) 0 \%$ & $(\mathrm{n}=1) 11.1 \%$ & $(\mathrm{n}=2) 22.2 \%$ & $(\mathrm{n}=5) 55.6 \%$ \\
\hline 2. & Halim Perdanakusuma $(\mathrm{n}=9)$ & $(\mathrm{n}=0) 0 \%$ & $(\mathrm{n}=0) 0 \%$ & $(\mathrm{n}=0) 0 \%$ & $(\mathrm{n}=2) 22.2 \%$ & $(\mathrm{n}=7) 77.8 \%$ \\
\hline 3. & Baru Ancol Selatan $(\mathrm{n}=8)$ & $(\mathrm{n}=0) 0 \%$ & $(\mathrm{n}=1) 12.5 \%$ & $(\mathrm{n}=0) 0 \%$ & $(\mathrm{n}=2) 25.0 \%$ & $(\mathrm{n}=5) 62.5 \%$ \\
\hline 4. & Antasari $(\mathrm{n}=18)$ & $(\mathrm{n}=0) 0 \%$ & $(\mathrm{n}=0) 0 \%$ & $(\mathrm{n}=0) 0 \%$ & $(\mathrm{n}=5) 27.8 \%$ & $(\mathrm{n}=13) 72.2 \%$ \\
\hline 5. & Kembangan Baru $(\mathrm{n}=3)$ & $(\mathrm{n}=0) 0 \%$ & $(\mathrm{n}=0) 0 \%$ & $(\mathrm{n}=0) 0 \%$ & $(\mathrm{n}=1) 33.3 \%$ & $(\mathrm{n}=2) 66.7 \%$ \\
\hline
\end{tabular}

When the type of discourse is taken into account, in Prapatan Road $55.6 \%$ of the signs belong to the Infrastructural discourse and the signs consist of no English words. Other Infrastructural signs (11\%) use fewer English words (vide Table 3). Indonesian, not English, is mostly prevalent for
Infrastructural discourse, which includes signs of buildings or tools that belong to, among others, the Jakarta Province, the Indonesian Federal Bank, the Indonesian Navy, the Mobile Brigade, the Fire Department, and the Indonesian Ministry of Finance.

Table 3. Discourse and language prevalence in Prapatan Road

\begin{tabular}{ccccccc}
\hline No. & $\begin{array}{c}\text { Type of Discourse } \\
(\mathrm{n}=9)\end{array}$ & $\begin{array}{c}\text { All English. } \\
(\mathrm{n}, \%)\end{array}$ & $\begin{array}{c}\text { More English } \\
(\mathrm{n}, \%)\end{array}$ & $\begin{array}{c}\text { Half English } \\
(\mathrm{n}, \%)\end{array}$ & $\begin{array}{c}\text { Fewer English } \\
(\mathrm{n}, \%)\end{array}$ & $\begin{array}{c}\text { No English } \\
(\mathrm{n}, \%)\end{array}$ \\
\hline 1. & Regulatory & - & - & - & $(\mathrm{n}=1) 11.1 \%$ & - \\
\hline 2. & Infrastructural & $(\mathrm{n}=1) 11.1 \%$ & - & $(\mathrm{n}=1) 11.1 \%$ & $(\mathrm{n}=1) 11.1 \%$ & $(\mathrm{n}=5) 55.6 \%$ \\
\hline
\end{tabular}

In Halim Perdanakusuma Road, $77.8 \%$ of the signs use no English words, which consist of both the Regulatory $(22.2 \%)$ and the Infrastructural $(55.6 \%)$ signs. The number of signs that belong to the Infrastructural discourse is higher than that belonging to the Regulatory discourse. The former discourse belongs to Halim Perdanakusuma
Airport, a state school, Coordinating Board for the National Family Planning building, and the Exhaust Emission Check-Point. The latter covers traffic signs. Only $22 \%$ of the signs that belong to the Infrastructural Discourse use fewer English words. There are no signs that consist entirely of English words. 
Table 4. Discourse and language prevalence in Halim Perdanakusuma Road

\begin{tabular}{lcccccc}
\hline No. & $\begin{array}{c}\text { Type of Discourse } \\
(\mathrm{n}=9)\end{array}$ & $\begin{array}{c}\text { All English. } \\
(\mathrm{n}, \%)\end{array}$ & $\begin{array}{c}\text { More English } \\
(\mathrm{n}, \%)\end{array}$ & $\begin{array}{c}\text { Half English } \\
(\mathrm{n}, \%)\end{array}$ & $\begin{array}{c}\text { Fewer English } \\
(\mathrm{n}, \%)\end{array}$ & $\begin{array}{c}\text { No English. } \\
(\mathrm{n}, \%)\end{array}$ \\
\hline 1. & Regulatory & - & - & - & - & $(\mathrm{n}=2) 22.2 \%$ \\
\hline 2. & Infrastructural & - & - & - & $(\mathrm{n}=2) 22,2 \%$ & $(\mathrm{n}=5) 55.6 \%$ \\
\hline
\end{tabular}

In Baru Ancol Selatan Road, 62.5\% of the signs do not display English words. The signs are both the Infrastructural $(37.5 \%)$ and Regulatory $(25.0 \%)$ discourses. The Infrastructural discourse includes signs by the General Election Commission office, a mosque, and a state school. The signs that are categorized into Regulatory discourse include a traffic sign and a public notice. Less than $30 \%$ of the signs, i.e. those that belong to the Infrastructural discourse (the District Court of North Jakarta and one educational foundation) use fewer English than Indonesian words.

Table 5. Discourse and language prevalence in Baru Ancol Selatan Road

\begin{tabular}{clccccc}
\hline & $\begin{array}{l}\text { Type of Discourse } \\
\text { No. }\end{array}$ & \multicolumn{5}{c}{ Language } \\
\cline { 2 - 7 } & $\begin{array}{c}\text { All English } \\
(\mathrm{n}, \%)\end{array}$ & $\begin{array}{c}\text { More English } \\
(\mathrm{n}, \%)\end{array}$ & $\begin{array}{c}\text { Half English } \\
(\mathrm{n}, \%)\end{array}$ & $\begin{array}{c}\text { Fewer English } \\
(\mathrm{n}, \%)\end{array}$ & $\begin{array}{c}\text { No English } \\
(\mathrm{n}, \%)\end{array}$ \\
\hline 1. & Regulatory & - & - & - & - & $(\mathrm{n}=2) 25.0 \%$ \\
\hline 2. & Infrastructural & - & $(\mathrm{n}=1) 12.5 \%$ & - & $(\mathrm{n}=2) 25,0 \%$ & $(\mathrm{n}=3) 37.5 \%$ \\
\hline
\end{tabular}

In Antasari Road, $72.2 \%$ of the signs use Indonesian words only. A higher percentage of the signs are Infrastructural $(50.0 \%)$ and the rest are Regulatory (22.2\%). The former include tax office, private houses, mosques, schools, and several services of the Jakarta province, while the latter includes a public notice by the sector police. Signs that use fewer English than Indonesian words are $27.8 \%$ only, all of them belong to the Infrastructural discourse.

Table 6. Discourse and language prevalence in Pangeran Antasari Road

\begin{tabular}{ccccccc}
\hline \multirow{2}{*}{ No. } & $\begin{array}{c}\text { Type of Discourse } \\
(\mathrm{n}=18)\end{array}$ & $\begin{array}{c}\text { All English } \\
(\mathrm{n}, \%)\end{array}$ & $\begin{array}{c}\text { More English } \\
(\mathrm{n}, \%)\end{array}$ & $\begin{array}{c}\text { Half English } \\
(\mathrm{n}, \%)\end{array}$ & $\begin{array}{c}\text { Fewer English } \\
(\mathrm{n}, \%)\end{array}$ & $\begin{array}{c}\text { No English } \\
(\mathrm{n}, \%)\end{array}$ \\
\hline 1. & Regulatory & - & - & - & - & $(\mathrm{n}=4) 22.2 \%$ \\
\hline 2. & Infrastructural & - & - & - & $(\mathrm{n}=5) 27,8 \%$ & $(\mathrm{n}=9) 50.0 \%$ \\
\hline
\end{tabular}

Kembangan Baru Road has the smallest number of signs among other areas. Of the total signs, $66.7 \%$ do not use English at all. Those signs belong to Regulatory and Infrastructural signs (33.3\% respectively). The Infrastructural discourse includes signs from one law foundation and one Islamic school, and the Regulatory discourse is found in the traffic notice. The rest of the signs use fewer English words.

Table 7. Discourse and language prevalence in Kembangan Baru Road

\begin{tabular}{ccccccc}
\hline No. & $\begin{array}{c}\text { Type of Discourse } \\
(\mathrm{n}=3)\end{array}$ & $\begin{array}{c}\text { All English. } \\
(\mathrm{n}, \%)\end{array}$ & $\begin{array}{c}\text { More English } \\
(\mathrm{n}, \%)\end{array}$ & $\begin{array}{c}\text { Half English } \\
(\mathrm{n}, \%)\end{array}$ & $\begin{array}{c}\text { Fewer English } \\
(\mathrm{n}, \%)\end{array}$ & $\begin{array}{c}\text { No English } \\
(\mathrm{n}, \%)\end{array}$ \\
\hline 1. & Regulatory & - & - & - & - & $(\mathrm{n}=1) 33.3 \%$ \\
2. & Infrastructural & - & - & - & $(\mathrm{n}=1) 33,3 \%$ & $(\mathrm{n}=1) 33.3 \%$ \\
\hline
\end{tabular}

It is obvious that English is not prevalent so long as the non-commercial signs are concerned in all of the research areas. Indonesian language is dominant. Thus, there can be two considerable differences between the non-commercial signs in Jakarta LL and the top-down signs in Tokyo (Backhaus, 2006) and Israel (Ben-Rafael et al., 2006). First, English has very limited occurrence. The language used in the government signs in Jakarta is primarily Indonesian, whereas the languages that occurred in the government signs in Tokyo LL were more various, i.e. Japanese, English, Chinese, and Korean, Similarly, in addition to Hebrew, Arabic, and English languages were present in Israeli LL. The language presentation of the non-commercial signs in Jakarta LL is more similar to that of Timor Leste LL in which Portuguese, not English was dominant (Macalister, 2012). Second, the primary audience of the noncommercial signs in Jakarta is Indonesian speakers, while the target audiences of Tokyo LL were both Japanese and groups of non-Japanese speakers and the audiences of Israeli LL were Hebrew, Arabic, and English speakers. The findings prove the noncommercial signs in Jakarta LL are exclusive, while the official signs in Tokyo and Israeli LLs tended to be inclusive. However, it is possible that the noncommercial signs in other contexts in Jakarta, such 
as airports or train stations, will show a contrary fact. The exclusiveness of the non-commercial signs may be similar to that of Timor Leste LL.

Despite the dominant use of Indonesian on the non-commercial signs in Jakarta LL, the use of English is unavoidable for few non-commercial signs. There can be several contributing factors behind the use of English in the non-commercial signs in Jakarta LL. First, the use of English may indicate efficiency. Texts in public signs are generally short, clear, and distinctive, as they require a very short time for the readers to read them (Gorter, 2006). Several words in English, for example, busway and separator are considered to be more efficient than the possible Indonesian versions jalur bus and pemisah jalur bus, respectively (vide Figure 4).

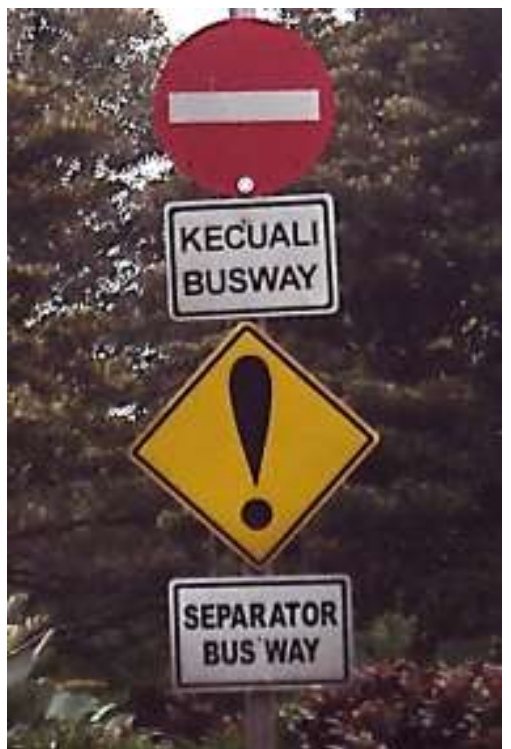

Figure 4. Regulatory discourse: busway and separator busway

Curiously, there are two meaning extensions. The first is with the noun busway (see Figure 4). While busway is defined as "a road or section of a road that can only be used by buses, especially the one with special tracks for guiding the buses" (Oxford Learner's Dictionaries, 2016), the above sign suggests that the meaning of busway has been extended into not only road but also the bus itself. The combination kecuali busway which is equal to except busway is the evidence. The second extension happens to the noun separator which is defined as "a machine for separating things" (Oxford Learner's Dictionaries, 2016). In Jakarta $\mathrm{LL}$, the meaning of separator is extended into a brick construction that separates the busway from the main road. Interestingly, the English noun separator is combined with the noun busway, in which the original meaning of busway is retained. Furthermore, there is an Indonesian acronym $H P$ (typically used in Indonesian context) that is derived from the English handphone. The item HP seems to be preferable because it is more efficient than the Indonesian version ponsel, which is a shortened form of telepon selular (cellular phone) or the English version handphone. The words $H P$, separator, and busway have been commonly used, but they have not been included in the Comprehensive Dictionary of Indonesian Language. Referring to Da Silva's (2016) Constellation, the items busway and separator may belong to Group 3, while $H P$ belongs to Group 4A. The study would like to propose that the lexical item $H P$ can be considered an Indonesian word because it has been pronounced /hape/ and not /eit $\int \mathrm{pi} /$.

Second, the absence of several English words such as $w w w, . g o$, .com, fax, web, GPS, and hydrant creates a semantic gap between English and Indonesian. Consequently, the use of English becomes unavoidable. The first three words above are operational, i.e. those words are needed to open a website address. They indicate the internet communication system, the research of which started in the US in the 1960s, a period of which English started its role as the internet lingua franca. The fact that all of the abovementioned words are related to technology indicates the privilege of English in relation to the Industrial Revolution (Crystal, 2003). Drawing from Da Silva's (2016) Constellation, the words com, .go, and web belong to Group 1A and the words GPS and hydrant belong to Group 1B.

Third, the prestige with the English words may be accounted for the use of English. Take the English words online and learning center, for example. The Indonesian versions for those words are available, i.e. dalam jaringan which was shortened into the acronym daring for online and pusat pendidikan dan latihan which was shortened into pusdiklat for learning center. That the English versions are still used is probably due to the prestige of English as in the use of English in French advertising (Martin, 2006). Finally, the use of the English airport instead of its Indonesian equivalent bandar udara or bandara can be related to the status of English as a language for international travel (Crystal, 2003).

\section{CONCLUSION}

In this study, I have highlighted what lies behind the language choice of non-commercial signs, the low prevalence of English, and the reason of using English words on the non-commercial signs. The analysis is limited into merely Place Semiotics. In the five research areas, both Regulatory and Infrastructural Discourses are present. Signs that belong to the Infrastructural Discourse are greater in number than those of the Regulatory Discourse. The English language is not prevalent. The Indonesian language is dominant. The choice of using English words may be related to the role of 
English as a lingua franca for the internet communication system, prestigious status of English, and role of English for international aviation. The use of Indonesian indexes the power of an authority (the government), while the use of English indexes the multiple roles of English. Future inquiries may specifically focus on the communication between the commercial and noncommercial signs, the object, the sign authors, and audience to construct identities in other places in Indonesia. Investigation on the use of local language to reveal the identity of a place may also be worth considering.

\section{REFERENCES}

Backhaus, P. (2006). Multilingualism in Tokyo: A look into the linguistic landscape. In D. Gorter, Linguistic landscape: A new approach to multilingualism (pp. 52-66). Clevedon: Multilingual Matters Ltd.

Ben-Rafael, E., Shohamy, E., Amara, M. H., \& Trumper-Hecht, N. (2006). Linguistic landscape as symbolic construction of the public space: The case of Israel. In D. Gorter, Linguistic landscape: A new approach to multilingualism (pp. 7-30). Clevedon: Multilingual Matters Ltd.

Boogaart II, T. A. (2001). The power of place: From Semiotics to Ethnogeography. Middle States Geographer, XXXIV, 38-47.

Busway. (n.d.) Oxford Learner's Dictionaries. (2016). Retrieved 21 July 2016 from www.oxfordlearnersdictionaries.com

Cenoz, J., \& Gorter, D. (2006). Linguistic landscape and minority languages. In D. Gorter, Linguistic landscape: A new approach to multilingualism (pp. 67-80). Clevedon: Multilingual Matters Ltd.

Creswell, J. W. (2013). Qualitative inquiry and research design: Choosing among five approaches. Los Angeles: SAGE Publications.

Crystal, D. (2003). English as a global language (2nd ed.). Cambridge: Cambridge University Press.

da Silva, A. M. (2016). On English prevalence and characteristics: A Case study of linguistic landscape along the main streets of five administrative towns in Jakarta (Unpublished Doctoral Dissertation). Atma Jaya Catholic University of Indonesia, Indonesia.

Dixson, A. E. (2015). Analyzing the multilingual linguistic landscape of Buffalo, New York. (Unpublished Master's Thesis) State University of New York, New York.

Edelman, L. (2010). Linguistic landscape in the Netherlands: A study of multilingualism in Amsterdam and Friesland. Utrecht: LOT.

Gorter, D. (2006). Further possibilities for linguistic landscape research. In D. Gorter, Linguistic landscape: A new approach to multilingualism (pp. 81-89). Clevedon: Multilingual Matters.

Huebner, T. (2016). Linguistic Landscape: History, trajectory and pedagogy. MANUSYA: Journal of Humanities, XXII, 1-11.

Koskinen, K. (2012). Linguistic Landscape as a translational space: The case of Hervanta, Tampere. Studies across Disciplines in the Humanities and Social Sciences, XIII, 73-92.

Lai, M. L. (2013). The linguistic landscape in Hong Kong after the change of sovereignty. International Journal of Multilingualism, X(3), 251-272. doi: http://dx.doi.org/10.1080/14790718.2012.7080 36

Landry, R., \& Bourhis, R. Y. (1997). Linguistic landscape and ethnolinguistic vitality: An empirical study. Journal of Language and Social Psychology, 16(1), 23-49. doi:10.1177/0261927X970161002

Macalister, J. (2012). Language policies, language planning and linguistic landscapes in TimorLeste. Language Problems \& Language Planning, XXXVI(1), 25-45. doi:10.1075/lplp.36.1.02mac

Manan, S. A., David, M. K., Dumanig, F. P., \& Naqeebullah, K. (2015). Politics, economics and identity: Mapping the linguistic landscape of Kuala Lumpur, Malaysia. International Journal of Multilingualism, XII(1), 31-50. doi: http://dx.doi.org/10.1080/14790718.2014.9055 81

Martin, E. (2006). Marketing identities through language: English and global imagery in French Advertising. New York: Palgrave Macmillan.

Mulyana, A. K. (2014, January 15). How to locate a centroid. (A. M. da Silva, Interviewer)

Ooi, V. B. (2001). Upholding standards or passively observing language? Corpus evidence and the concentric circles model. In V. B. Ooi, Evolving identities: The English language in Singapore and Malaysia (pp. 168-183). Singapore: Times Academic Press.

PT. Transportasi Jakarta. (2016). BERANDA/TENTANG TRANSJAKARTA/SEJARAH. Retrieved from: http://transjakarta.co.id

Scollon, R., \& Scollon, S. W. (2003). Discourses in place: Language in the material world. London: Routledge.

Stroud, C., \& Jegels, D. (2013). Semiotic landscapes and mobile narrations of place: Performing the local. Tilburg: Tilburg University.

Taylor-Leech, K. J. (2012). Language choice as an index of identity: linguistic landscape in Dili, Timor Leste. International Journal of Multilingualism, IX(1), 15-34. doi: http://dx.doi.org/10.1080/14790718.2011.5836 54 
Torkington, K. (2009). Exploring the linguistic landscape: The case of the 'Golden Triangle' in the Algarve, Portugal. Lancaster University
Postgraduate Conference in Linguistic and Language Teaching. III, 122-144. Lancaster: Lancaster University Postgraduate.

i The article is based on an unpublished dissertation entitled "On English Prevalence and Characteristics: A Case Study of Linguistic Landscape Along the Main Streets of Five Administrative Towns in Jakarta" 